\title{
УПРАВЛІННЯ ЯКІСТЮ ОСВІТНІХ ПОСЛУГ У ВІДКРИТОМУ УНІВЕРСИТЕТІ
}

Сорочан Т. М., доктор педагогічних наук, професор, директор Центрального інституту післядипломної освіти ДЗВО «Університет менеджменту освіти», Київ, Україна, DOI: https://doi.org/10.31435/rsglobal_conf/25012021/7356

\begin{abstract}
The article is devoted to the issue of quality provision in respect of educational services rendered by the open university which is regarded as an innovative digital educational and scientific environment. The article gives substantiation and features the results achieved in approbation process of modern model applied for management of educational services quality in open university; this model is presented as the one which provides competitiveness of specialists in the labor market in conditions of social instability and uncertainty. In particular, the article characterizes such aspects as the influence of educational economics upon apprehension of educational services quality, the importance of transformational education applied to ensure the competitiveness of students in the labor market, the management basics of open university considered by the example of functioning of non-formal education system at SEE "University of Education Management" at NAES of Ukraine. The article features the orientation of transformational pedagogy at formation and development of complex (interdisciplinary) mentality of specialists, as well as at their ability to overcome obstacles in activities and to critically analyze different situations, to participate in joint problems solving, to find creative approaches and alternatives.
\end{abstract}

Keywords: open university, transformational education, professional development, economics of education, quality of educational services, management of open universities, quality management of educational services, virtual department.

Вступ. Сучасний стан освіти визначається новітніми тенденціями: розумінням іiі як потужного чинника розвитку економіки і людського капіталу, посиленням відкритості освіти в умовах цифровізації життєдіяльності громадян, зростанням вимог суспільства, держави, здобувачів до якості освіти і освітніх послуг.

На тому, що освіта $€$ визначальним чинником інноваційного типу прогресу людства в епоху суспільства знань, неодноразово наголошував В. Кремень у своїх наукових працях $\mathrm{i}$ публічних виступах [4; 6].

Можна стверджувати, що на часі пошук нових підходів до технологій освіти, управління iї якістю з метою реалізації суспільно значущої місії - розвитку людського капіталу й особистісного розвитку кожної людини.

Цінність освіти для суспільства полягає в отриманні вигоди від того, що фахівці з більш високим рівнем освіченості можуть приносити більший дохід. Вищий рівень освіти зумовлює підвищення продуктивності праці, що має виявлятися у зростанні індивідуального доходу працівника. Чим вищий рівень освіти людського капіталу, тим вищі потенційні можливості для росту продуктивності праці в національній економіці і тим більшим має бути сукупний дохід суспільства. Таким чином, існує тісний зв'язок між освітою та економічним зростанням, що може виявлятися в темпах росту загальних економічних показників: валового національного продукту, валового внутрішнього продукту тощо. Вплив освіти на розвиток національної економіки є багатовекторним: прямо і опосередковано освіта поліпшує якісні характеристики економічного розвитку, суттєво впливає на культурне середовище, політичну сферу тощо. Саме тому освіта як сфера суспільної діяльності розглядається науковцями як продуктивна. Вона $\epsilon$ частиною невиробничої сфери, але результати освітньої діяльності виявляються у зростанні продуктивності інших економічних та соціальних сфер.

Інша найважливіша економічна функція освіти полягає в задоволенні освітніх потреб людей. Специфічним товаром, що постачає на ринок освіта, $\epsilon$ освітні послуги, які й задовольняють освітні потреби. Освіта як галузь належить до нематеріального виробництва, роль якого в сучасному інформаційному суспільстві постійно зростає. Економіка високорозвинених країн фактично вже стала економікою послуг. Це актуалізує дослідження проблем управління якістю освітніх послуг.

Сучасне суспільство можна охарактеризувати як суспільство знань, що перебуває в активній стадії цифровізації. Віддзеркаленням цих тенденцій $є$ поширення дистанційного навчання, онлайн комунікації, відповідно, затребуваності освітніх послуг відкритих університетів. 
Мета статті полягає в обгрунтуванні та апробації сучасної моделі управління якістю освітніх послуг у відкритому університеті, що забезпечує конкурентоспроможність фахівців на ринку праці в умовах соціальної нестабільності і невизначеності.

У ході дослідження з використанням методів аналізу наукових і статистичних джерел, спостереження, анкетування, моделювання нами було виокремлено декілька чинників управління якістю освіти у відкритому університеті: врахування економіки сучасної освіти, трансформаційне навчання фахівців, особливості управління професійним розвитком фахівців у контексті надання якісних освітніх послуг у відкритому університеті.

Дослідження проблеми управління якістю освітніх послуг у відкритому університеті базувалося на таких вихідних положеннях:

$>$ людиноцентризм як методологія розвитку людського капіталу, забезпечення якості і безперервності освіти (В Кремень);

$>$ економіка освіти, сучасні підходи до розуміння якості освіти як економічної категорії (І. Каленюк, С. Клепко, О. Падалка);

$>$ ідеологія цифрового суспільства, поширення цифрових технологій у суспільстві знань, створення інформаційно-освітнього й освітньо-наукового середовища в університетах (В. Биков, М. Кириченко, В. Кремень, Л. Панченко, О. Спірін);

нові технології освіти дорослих і післядипломної освіти (О. Аніщенко, В. Гравіт, Л. Лук'янова, Н. Ничкало, В. Олійник, Ю. Хасіневич);

$>$ трансформаційне навчання (Дж. Мезіров (J. Mezirow), Р. Бойд (R. Boyd);

$>$ трансформація професіоналізму у відкритому університеті (Т. Сорочан).

Результати. У ході наукового пошуку встановлено, що міжгалузеві дослідження у сфері економіки й освіти зосереджують увагу на таких аспектах, як вплив освіти на економічний розвиток країни; розуміння освіти як інвестиційної сфери й економічної галузі; особливості надання освітніх послуг і визначення їхньої якості $[3 ; 6 ; 8]$.

Можна констатувати, що освіта $є$ важливою для сталого розвитку суспільства, забезпечення прогресу в науці, технологіях, виробництві, оскільки визначальним чинником цих процесів є людські ресурси. Розвиток людських ресурсів забезпечується багатьма чинниками, а саме: освіта, охорона здоров'я, зайнятість, політичні та економічні свободи тощо. Вони всі взаємопов'язані і взаємозалежні, проте провідна функція належить освіті.

Освіта як галузь економічної діяльності, по-перше, має продуктивну природу, вона здатна давати віддачу і в короткостроковому періоді у вигляді зростання доходу та прибутку, i в довгостроковому, що зумовлює рентабельність інвестицій в освіту. По-друге, функціонування освіти як системи передбачає необхідність налагодження відповідного ефективного процесу. Це завдання досить складне, що зумовлено специфікою освіти як суспільного блага, яке не може продукуватися і розподілятися лише за допомогою ринкового механізму. Водночас, механізм функціонування освітньої галузі та окремих закладів обов'язково включає економічні виміри: покриття витрат доходами, економії ресурсів, більш ефективного використання коштів тощо.

Економічний аналіз потребує характеристики продукту, що виробляється, а також особливостей організації виробничого процесу саме цього продукту. Економіка освіти передбачає врахування специфіки освітніх послуг, аналіз відповідних витрат, особливостей технологічного (освітнього) процесу, одержаних результатів [8].

Отже, об'єктом аналізу економіки освіти виступає система освіти, ії економічний механізм функціонування, процес виробництва і надання освітніх послуг, встановлення їхньої вартості. Важливим є економічний характер результатів освітньої діяльності, властивості і якість освітніх послуг.

Освіта надає специфічні послуги з формування компетентностей, передавання цінностей, інформації, знань, досвіду діяльності. Отже, з позицій економіки продуктом освіти можуть вважатися освітні послуги як специфічні блага. Освітні послуги надаються в процесі здійснення різних видів професійної педагогічної діяльності (освітньої, наукової, методичної, виховної тощо) з метою задоволення потреб окремих людей та всього суспільства, громадян різного віку та різних соціальних груп.

Смисли поняття «освітня послуга» можуть бути такими:

$>$ діяльність, результати якої не є матеріальними, а реалізуються і споживаються в процесі самої діяльності;

$>$ робота окремого педагога або педагогічного колективу, спрямована на соціальнопсихологічні зміни особистості тих, хто навчається; 
$>$ діяльність з реалізації основних цілей освіти;

$>$ формування у здобувачів освіти компетентностей (цінностей, знань, умінь), що використовуються для задоволення різноманітних потреб людини, суспільства, держави.

Економіка освіти створює передумови для формування нових підходів до управління якістю освіти. Сучасне розуміння якості освітніх послуг 3 позицій економіки враховує показники двох рівнів - зовнішнього, статистичного, і внутрішнього, що свідчить про результат сформованість компетентностей. Перший рівень показників важливий для управлінських структур, держави, громадськості, суспільства, оскільки дає можливість визначити ефективність з позицій співвідношення витрат ресурсів і кількісних показників надання освітніх послуг. Другий рівень показників, крім вищезазначених стейкхолдерів, $\epsilon$ важливим для споживачів, замовників освітніх послуг і роботодавців, оскільки саме сформованість компетентностей і здатність до їх застосування визначає конкурентоспроможність здобувачів освіти на ринку праці.

Поняття якості освіти походить із економіки освіти і означає відповідність результатів освіти певним стандартам. Розуміння природи і сутності освітніх послуг, їхньої спрямованості на задоволення освітніх потреб здобувачів освіти і запитів суспільства та держави лежить в основі управління якістю освітніх послуг шляхом створення і реалізації сучасних моделей освіти.

У сучасних умовах основою конкурентоспроможності фахівця є його здатність до активної участі у різних видах діяльності. Зорієнтованість освіти на високий рівень якості освітніх послуг і готовність кадрів до роботи в умовах соціальної невизначеності, нестабільності ринку праці актуалізує опанування трансформаційної педагогіки. Саме вона здатна забезпечити швидку зміну стану професіоналізму фахівців і тим самим підвищити їхню конкурентоспроможність на ринку праці.

Трансформаційна педагогіка спрямована на формування та розвиток комплексного (міждисциплінарного) мислення, інклюзії, здатності долати перешкоди в діяльності і критично аналізувати різні ситуації, брати участь у спільному вирішенні проблем, знаходити творчі підходи й альтернативи. Такі здатності особистості як результат трансформаційної педагогіки мають сприяти глобальним соціальним змінам у суспільстві, подоланню невизначеності щодо майбутнього.

Методи трансформаційної педагогіки мають відповідати особливостям цільової групи, враховувати контекст навчання, підтримувати культурні традиції певної категорії населення. Трансформаційна педагогіка відзначається застосуванням інтерактивних методів, проблемністю, трансдисциплінарністю, поєднанням формальної і неформальної освіти. Вона грунтується на заохоченні до співпраці, взаємодії, спільної діяльності, самостійності в навчанні, прагненні до саморозвитку. Її основами є: орієнтація на того, хто навчається; орієнтація на дію в навчанні; трансформаційне навчання.

Трансформаційне навчання розглядається як спеціально організована спільна діяльність суб'єктів навчання (педагогів і здобувачів освіти) щодо обміну знаннями, уміннями, досвідом 3 метою зміни світоглядних установок та ціннісних орієнтацій, опанування нових знань та способів діяльності, результатом чого має стати набуття особистістю компетентностей, які дають змогу підвищити якість життя, рівень професіоналізму відповідно до змін соціуму або особистих життєвих обставин $[10,13]$.

Основи теорії та практики трансформаційного навчання (transformative learning) заклав Дж. Мезіров (J. Mezirow) [13]. На його думку, трансформація - це процес, у якому особистість критично усвідомлює, яким чином і чому в неї сформовано певну картину світу, розуміння того, яким чином можна змінити іiі та моделі поведінки, а також остаточний вибір щодо оновлення діяльності на основі цього нового розуміння.

Дж. Мезіров (J. Mezirow) та інші представники цього напряму досліджень (Р. Бойд (R. Boyd), C. Брукфілд (S. Brookfield), Д. Діркс (J. Dirkx), Дж. Майєрс (J. Myers) та ін.) [12, 13] уважали, що трансформаційна або перетворювальна освіта спрямовується на перспективу зміни ставлень, цінностей, ментальності, дій особистості у трьох вимірах: психологічному (зміни в розумінні себе), ціннісному (зміна переконань) та поведінковому (зміна стилю життя).

Поштовхом до трансформаційного навчання для особистості, стверджують дослідники, $\epsilon$ ситуація невизначеності, необхідності діяти в обставинах, які $є$ викликом інтелектуальним, емоційним, соціальним, моральним або їх поєднанням. Така ситуація може спершу викликати стрес, невпевненість, але потім спонукає до пошуку нових поглядів та перспектив. Трансформація починається тоді, коли людина набуває здатності бачити власну ситуацію в іншому аспекті. За таких умов вона потребує не отримання нової інформації у процесі 
навчання, а нового досвіду для усвідомлених змін. Це супроводжується переосмисленням переконань, цінностей, аналізом різних поглядів.

Трансформаційне навчання як сучасна освітня технологія розглядається нами як спеціально організована взаємодія педагогів та здобувачів освіти щодо опанування цінностей суспільства знань, обміну знаннями, уміннями, досвідом 3 метою підготовки до життєдіяльності та професійної самореалізації в умовах постійних суспільних змін або невизначеності життєвих обставин [10].

Трансформаційне навчання дорослих здобувачів освіти характеризується спрямованістю на зміну світоглядних установок та ціннісних орієнтацій, на опанування нових знань та способів діяльності, результатом чого має стати готовність дорослої особистості до життя і професійної діяльності в умовах інноваційного типу прогресу людства (за В. Кременем) [4; 6]. Воно передбачає особисту відповідальність за результат, зміну зовнішнього контролю на внутрішній. Навчання має проводитись з урахуванням соціального контексту, а дорослі - бути переконаними в тому, що саме i 3 якою метою вони вивчають, як це пов'язано 3 їхнім особистим життям або професійною діяльністю.

Оскільки професійна діяльність є важливою для дорослої людини, сучасні технології трансформаційного навчання значною мірою спрямовуються на трансформацію професіоналізму. Трансформація професіоналізму - якісна швидка його, зумовлена набуттям фахівцем нового рівня здатності і готовності до професійної діяльності в умовах цифрового світу та суспільства знань.

У суспільстві і державі зростає попит на відкриту, доступну широким верствам населення, безперервну освіту, технологічно інноваційну, що надає широкі можливості для індивідуалізації, вибору змісту навчання, професійного і особистісного розвитку.

Однією із визначальних характеристик сучасної освіти $є$ її безперервність. Безперервна освіта розглядається як поступовий процес набуття особистістю компетентностей, цінностей, знань, умінь, досвіду, що в різних формах триває впродовж життя і може відбуватися як перехід з однієї ланки формальної системи освіти до іншої (від дошкільної - до вищої і післядипломної). У процесі безперервної освіти людина також використовує можливості неформальної (освіти в сім’ї, участі у гуртках, творчих колективах, тренінгах, семінарах, майстер-класах, конференціях тощо) та інформальної освіти (самоосвіти).

У більшості досліджень безперервність освіти розглядається як стратегічний орієнтир суспільного прогресу. Вона $\epsilon$ не лише провідним фактором соціально-економічного розвитку суспільства, а й важливою умовою розвитку особистості, її творчого потенціалу [7].

Важливу роль у залученні особистості до безперервної освіти відіграють освітні потреби, вплив соціуму, сім'ї, спосіб життя, а в дорослої людини - ще й мотиви професійного розвитку та кар'єри.

Отже, сучасна освіта набуває ознак відкритості і безперервності, тому в світі поширюється і стає затребуваним досвід відкритих, віртуальних університетів.

Відповідний досвід уперше в світі був започаткований у Великій Британії. Британський віртуальний університет відкритої освіти заснований указом іiі величності королеви Великої Британії у 1969 р. Мета його створення - надати можливість людям навчатися у зручному для них місці і в зручний час. Відтак понад три мільйони студентів пройшли там курс навчання. Офіси закладу знаходяться у тринадцяти регіонах країни, а також у понад п’ятдесяти державах світу.

Віртуальні відкриті університети надають освітні послуги за дистанційною формою навчання. Прикладами таких закладів $є$ Державний університет губернаторів (США), Канадський відкритий університет, Голландський відкритий університет та інші. Усього їх функціонує в різних країнах світу понад п’ятдесят.

Наше дослідження дає можливість стверджувати, що віртуальний відкритий університет - це інноваційне освітньо-наукове середовище, яке забезпечує реалізацію функцій освіти та надання освітніх послуг у сфері вищої і післядипломної освіти засобами цифрових технологій на засадах цінностей суспільства знань.

Віртуальний університет - це середовище комунікації і співпраці, де розширюються можливості доступу здобувачів освіти, широких верств населення, фахівців, окремих осіб із розвинутими освітніми потребами до бази знань. Також забезпечується можливість для них стати учасниками творення цієї бази знань, що є сутнісною ознакою сучасної стадії розвитку суспільства. Викладачі віртуального відкритого університету разом із здобувачами освіти $\epsilon$ 
дослідниками, вони зростають академічно і професійно, запроваджують результати досліджень у практичну діяльність.

Академічна стратегія віртуального університету спрямована на реалізацію концепції безперервної освіти впродовж життя на основі інноваційних технологій вищої і післядипломної освіти, забезпечення якості освіти, професійного розвитку фахівців. Освіта, навчання, дослідження, особистісний i професійний розвиток суб'єктів освітнього процесу у віртуальному університеті стають самоцінністю. У соціально-педагогічному контексті відкритий університет дає змогу задовольнити потреби суспільства, культури, економіки, управління. В особистісному вимірі його діяльність спрямовується на забезпечення індивідуальної освітньої траєкторії відповідно до різноманітних освітніх запитів, розширення аудиторії споживачів освітніх послуг.

Віртуальний відкритий університет забезпечує потрібні передумови для безперервного професійного розвитку здобувачів освіти, координації освітньої, дослідницької, методичної, наукової діяльності його суб'єктів [5].

Провідними напрямами діяльності віртуального відкритого університету є такі: створення мобільного освітнього простору для студентів, слухачів і викладачів з використанням мережевих цифрових технологій навчання з метою розширення доступу до якісної освіти, створення умов для здобуття додаткової освіти та відпрацювання інших складових системи безперервної освіти; розвиток електронної мережі навчальних курсів, підручників для поліпшення інформаційного забезпечення освітнього процесу; розширення можливостей слухачів та студентів щодо вибору варіантів навчальних програм i форм навчання за різними напрямами i спеціальностями; поліпшення якості освіти, проведення наукових заходів; розроблення системи єдиного обліку навчальних модулів і кредитів, напрацювання технологій оцінювання якості освітнього процесу та результатів навчання здобувачів освіти; організація ефективної системи перепідготовки та підвищення кваліфікації фахівців різних галузей; здійснення міжнародної діяльності у сфері освіти і науки відповідно до чинного законодавства.

Віртуальний відкритий університет $є$ перспективною моделлю безперервної освіти впродовж життя на основі цифрових технологій $[9 ; 11]$. Освітня, наукова, методична діяльність у відкритому університеті здійснюється віртуальними кафедрами, які об'єднують ресурси партнерів для забезпечення освітніх потреб споживачів освітніх послуг. Важливою функцією віртуального університету та віртуальних кафедр $є$ реагування на зміни суспільних і ринкових вимог до фахівців різних галузей, надання їм можливостей професійного розвитку, трансформації професіоналізму на основі нових цінностей, оновлення знань та опанування сучасних технологій професійної діяльності.

Ідею, концепцію, організацію віртуального університету як інноваційної моделі безперервної освіти, особистісного i професійного розвитку фахівців реалізовано в Університеті менеджменту освіти Національної академії педагогічних наук України. Український відкритий університет післядипломної освіти (УВУПО) набув розвитку як інноваційна альтернативна модель неформальної післядипломної освіти. Він провадить освітню діяльність, пов'язану з підвищенням кваліфікації, професійним розвитком фахівців у різних галузях знань, здійснює прикладні наукові дослідження, сприяє поширенню наукових знань, зокрема в галузі освіти дорослих. Освітній процес здійснюється на автентичній платформі LMS AdL (Learning Management System Adult Learning), розробниками якої $€$ В. Олійник, М. Кириченко, Т. Сорочан, Л. Карташова, С. Ларін.

Аналіз першого досвіду діяльності УВУПО дає підстави для визначення засад забезпечення якості освітніх послуг.

Відправною точкою є дотримання високих академічних стандартів, які втілені у відповідні курикулуми курсів інноваційного змісту, що пропонуються здобувачам освіти. Вони створюють передумови для задоволення освітніх потреб і запитів різноманітних категорій як споживачів освітніх послуг, так і замовників освітніх послуг, стейхолдерів.

Важливим чинником якості освітніх послуг є усвідомлення і дотримання цінностей відкритої освіти, а саме: людиноцентризм (за В. Кременем) [4], безперервність, інноваційна спрямованість навчання, визнання пріоритетного права людини на особистісний і професійний розвиток, а також на вільний вибір змісту, форм, термінів, технологій навчання. Такі цінності $\epsilon$ основою взаємодії УВУПО зі слухачами, розширення меж доступності громадян до навчання, пошуку нових підходів до провадження освітнього процесу. 
Дослідницький потенціал УВУПО і наявні конкретні результати наукових досліджень дають можливість представити у змісті освіти різні галузі знань, аспекти культури, економіки, громадянської освіти, публічного управління й управління освітою тощо.

Особливої уваги заслуговує професіоналізм викладачів УВУПО, розробників курсів, курикулумів, дослідників i носіїв інновацій. Саме цей чинник $є$ найбільш вагомим у забезпеченні конкурентоспроможності УВУПО на ринку освітніх послуг.

Дистанційне навчання у відкритому університеті передбачає створення широких можливостей для комунікації управлінських структур, організаторів освітнього процесу, викладачів, слухачів, усіх зацікавлених осіб. Комунікація передбачає зворотній зв'язок 3 віртуальною аудиторією в цілому і кожним окремим слухачем або потенційним споживачем освітніх послуг, рефлексію й евалюацію, мотивацію слухачів до післядії по завершенні курсу.

Безперервний професійний розвиток, що є пріоритетом УВУПО, - це процес набуття фахівцем сутнісних ознак професійної самосвідомості та професійної культури вищого рівня, а також здатності до виконання більш складних функцій професійної діяльності, оновлення наявних і формування нових компетентностей, що характеризується діалектичною єдністю певних етапів навчання і самоосвіти, відбувається як доцільна послідовність різних форм i технологій формальної, неформальної й інформальної освіти.

Основним структурним підрозділом УВУПО є віртуальна кафедра - інноваційне цифрове середовище, що поєднує інтелектуальний, науковий, професійний, освітній, технологічний потенціал окремих суб'єктів з метою забезпечення якості освітнього процесу на основі цифрових технологій у віртуальному просторі.

У діяльності віртуальної кафедри на добровільних партнерських засадах можуть брати участь установи і заклади освіти, окремі кафедри, науковці, громадські організації тощо. Організаційна структура віртуальної кафедри характеризується опосередкованим управлінням, незалежністю учасників, передбачає наявність договірних взаємин між ними.

За аналогією з кафедрою як базовою університетською структурою віртуальна кафедра забезпечує якість освітнього процесу за певним напрямом з підготовки і післядипломної освіти фахівців різних галузей на основі системних наукових досліджень, розроблення сучасних методик, технологій провадження освітнього процесу, зорієнтована на задоволення освітніх потреб споживачів освітньої послуги. Створення віртуальних кафедр віддзеркалює клієнтоцентровану стратегію в освіті, сприяє поліпшенню організаційної гнучкості, реагуванню на нововведення.

Віртуальна кафедра може створюватися на основі кафедри, яка функціонує в закладі вищої освіти. Як об'єднання реальних і віртуальних структур вона має синергетичний ефект навчання здобувачів освіти в системі формальної і неформальної освіти, може посилити переваги та компенсувати окремі недоліки в кадровому і методичному забезпеченні, плеканні традицій, поширенні досвіду.

Віртуальна кафедра функціонує як віртуально-інтегрована спільнота творчих, соціально-активних фахівців міжпредметної й трансдисциплінарної сфер, вітчизняних та іноземних педагогів, що здійснює освітню, наукову, методичну та організаційну діяльність, зорієнтоване на спільну реалізацію отриманих результатів, створення доступної бази знань, поширення досвіду. Вона забезпечує відкритий доступ до наукових досліджень, здійснених у межах означеного співтовариства, що передбачає використання мережі дистанційного зв'язку; послідовне формування освітнього віртуального співтовариства фахівців певної галузі знань; маркетинг знань i дистанційних освітніх послуг; захист спільного використання інтелектуальної власності членів віртуальної кафедри; інтеграцію розгалужених освітніх практик до цілісної системи безперервної освіти фахівців.

Серед переваг віртуальної кафедри вирізняються такі: усвідомлення учасниками потреби в досвіді та ресурсах один одного, об'єднання на цій основі ресурсів для реалізації спільних цілей; електронна інтеграція кращих розробок; кооперація та координація віддалених партнерів; можливість гнучкого реагування на зміни середовища, ринку праці; реалізація міждисциплінарної стратегії навчання; формування гнучких навчальних груп, можливість індивідуального навчання. Віртуальна кафедра - частина мережевої інфраструктури, яка реалізує освітні технології на засадах міждисциплінарного підходу.

Висновки. Отже, УВУПО на основі кращого досвіду професійного розвитку фахівців, використання цифрових технологій забезпечує трансформаційне навчання здобувачів освіти, в результаті чого відбувається якісна зміна компетентностей, затребуваних на сучасному ринку праці. 
Здатність УВУПО працювати на випередження освітніх змін, ураховувати тенденції реформування системи освіти, своєчасно забезпечувати підготовку кадрів до роботи в умовах запровадження великої кількості інновацій зумовлює його конкурентоздатність у сучасних умовах.

Управління якістю освітніх послуг у відкритому університеті, модель якого реалізована в УВУПО, передбачає орієнтацію на такі пріоритети:

$>$ реалізація інноваційної віртуальної моделі УВУПО як перспективної форми надання освітніх послуг високої якості у сфері формальної та неформальної освіти;

$>$ організація освітнього процесу в УВУПО на засадах відкритої освіти, партнерства, андрагогічного, акмеологічного, синергетичного, кластерного підходів;

$>$ забезпечення якості освітніх послуг в УВУПО на основі інноваційного контенту та технологій трансформаційного навчання.

Управління якістю освітніх послуг в УВУПО на етапі його становлення було спрямовано на розроблення і запровадження таких цифрових ресурсів:

$>$ автентична веб-платформа для навчання дорослих «Система управління навчанням дорослих (Learning Management System Adult learning)» - LMS AdL.

$>$ сайт «Український відкритий університет післядипломної освіти» http://uvu.org.ua/;

$>$ електронне освітне середовище для дистанційного навчання

http://uvupo.ues.net.ua/index.php/ua/;

$>$ віртуальні кафедри:

- андрагогіки http://uvu.org.ua/kafedra-osvity-doroslykh/;

- управління освітою http://uvu.org.ua/kafedra-upravlinnia-osvitoiu/;

- професійної освіти http://uvu.org.ua/kafedra-profesiinoi-osvity/;

- психологіï http://uvu.org.ua/kafedra-psykholohii/;

- цифрових технологій http://uvu.org.ua/kafedra-tsyfrovykh-tekhnolohii/

- Нової української школи http://uvu.org.ua/kafedra-nush/.

Управління освітньою, науковою, методичною, організаційною діяльністю педагогічних і науково-педагогічних працівників, які забезпечують освітній процес в УВУПО, спрямоване на висвітлення досягнень сучасної науки в освітньому процесі, запровадження трансформаційного навчання, визначення якості освітніх послуг і результатів навчання за об'єктивними науково обгрунтованими критеріями.

Задоволені якістю освітніх послуг УВУПО й постійно обирають його для професійного розвитку працівники різних закладів освіти України, зокрема, вищої - 39, професійної (професійно-технічної) - 44, загальної середньої - 30, фахової передвищої - 20, післядипломної - 15, інших закладів - 13. Слухачами курсів підвищення кваліфікації стали представники 23 областей України та міста Києва.

Освітній процес забезпечено 65 науково-педагогічними працівниками. Для забезпечення дистанційного навчання слухачів на курсах підвищення кваліфікації в електронному освітньому середовищі УВУПО створено понад 80 електронних кабінетів викладачів, розміщено понад 300 матеріалів у веб-бібліотеці.

В УВУПО також було проведено онлайн понад 70 методичних заходів (у формі вебінарів, конференцій, форумів, «толоки», «марафону» тощо), у тому числі - 2 відкриті засідання віртуальних кафедр. У заходах узяли участь понад 5000 осіб, кількість подальших переглядів у мережах - понад 7000. Інформація щодо діяльності УВУПО активно поширюється у соцмережах, де функціонують сторінки науково-педагогічних працівників, груп, УВУПО. Усього охоплена віртуальна аудиторія близько 40 тис. користувачів.

Таким чином, інноваційну модель управління якістю освітніх послуг в УВУПО можна вважати апробованою і готовою до широкого використання.

Подальші напрями досліджень будуть пов'язані 3 обгрунтуванням критеріїв встановлення рівня якості освітніх послуг у неформальній освіті, вдосконаленням діяльності віртуальних кафедр як основних структурних підрозділів відкритого університету, визначенням чинників впливу економіки освіти на розвиток різних моделей організації освітнього процесу.

Загальні висновки полягають у тому, що сучасне розуміння якості освітніх послуг грунтується на дослідженнях у галузі економіки освіти. Здобувачі освіти, замовники освітніх послуг висувають високі вимоги до якості освіти, оскільки мають потребу бути конкурентоспроможними на нестабільному ринку праці. Задовольнити запити держави $\mathrm{i}$ суспільства, особисті освітні потреби здобувачів освіти можливо лише із застосуванням 
сучасних моделей i технологій освітнього процесу, що створюють передумови для забезпечення належного рівня якості освітніх послуг. Такою інноваційною моделлю $\epsilon$ відкритий університет, а провідною технологією - трансформаційне навчання. Управління якістю освіти у відкритому університеті спрямовується на розвиток людського капіталу на основі сучасних цифрових технологій.

\section{ЛIТЕРАТУРА}

1. В. Ю. Биков, В. Г. Кремень, Категорї̈ простір $і$ середовище: особливості модельного подання та освітнього застосування Теорія і практика упр. соц. системами: філос., психологія, педагогіка, соціол. (2), 2013. - стор. 3-16.

2. М.О. Кириченко, Формування ідеології інформаційного суспільства в умовах глобальної інформатизації: тенденції, парадигми, перспективи розвитку: [Монографія] / Микола Кириченко; Мін-во освіти і науки України, Університет менеджменту освіти НАПН України. - Харків: Вид-во ПП «Технологічний Центр», 2017. - 320 с.

3. С. Клепко, Економіка освіти з точки зору філософії освіти, Управління освітою. 2007. №7(151). С. 10 - 17

4. В.Г. Кремень Філософія людиноцентризму в стратегіях освітнього простору [Текст]: монографія / В.Г. Кремень ; АПН України. - К. : Педагогічна думка, 2009. - 520 с.

5. Науково-методичні основи модернізації освітньої діяльності вищих навчальних закладів післядипломної педагогічної освіти на засадах сучасних технологій: зб. наук. пр. / [В.В. Олійник та ін.; редкол.: В.В. Олійник, В.О. Гравіт, С.Ю. Хасіневич]; Нац. акад. пед. наук України, Ун-т менеджменту освіти. - Київ : УМО НАПН України, 2014. - 275 с.

6. Національна доповідь про стан і перспективи розвитку освіти в Україні. - Київ, 2016: Педагогічна думка.

7. Концептуальні засади розвитку освіти дорослих: світовий досвід, українські реалії і перспективи: збірник науковий статей/за ред. Кременя В.Г., Ничкало Н.Г.; укл. Аніщенко О.В., Лук'янова Л.Б. К.: Знання України, 2018. 616 с.

8. О. С. Падалка, І. С. Каленюк, Економіка освіти та управління: посібник, - К.: Педагогічна думка, 2012.- $184 \mathrm{c}$

9. Л. Ф. Панченко, Інформаційно-освітнє середовище сучасного університету: монографія / Л. Ф. Панченко; держ. закл. Луган. нац. ун-т імені Тараса Шевченка. Луганськ, вид-во Д3 «ЛНУ імені Тараса Шевченка», 2010. - 280с.

10. Т.М. Сорочан, Технології освіти дорослих у вимірі трансформації професіоналізму фахівців, Відкрита освіта: інноваційні технології та менеджмент: колективна монографія / за наук. ред. М. О. Кириченка, Л. М. Сергеєвої - Київ: Видавництво інституту обдарованої дитини НАПН України, 2018. - 440c. - C. 82-102.

11. О. М. Спірін, (2019) Інформачійно-циифрові технологї̈ підтримки науково-педагогічних досліджень в університеті In: Інформаційно-цифровий освітній простір України: трансформаційні процеси $\mathrm{i}$ перспективи розвитку, 4 квітня 2019 року, м. Київ, Україна. http://lib.iitta.gov.ua/717839/

12. Boyd, D.Robert, and Myers, J. Gordon. Transformative Education. International Journal of Lifelong Education 7, no. 4 (October-December 1988), 261-284.

13. Mezirow, J. (2003). Transformative learning as discourse. Journal of Transformative Learning, 1, 58-63.

14. T. Sorochan Transformation of educators' professionalism in the system of post-graduate teacher education: Modern Discourses, 2018, 1, 192-199. 